\title{
Code switching
}

Michael Clyne

\section{(QpenEdition}

Journals

Electronic version

URL: http://journals.openedition.org/esp/2827

DOI: $10.4000 /$ esp.2827

ISSN: 2532-0319

\section{Publisher}

Centre d'Information sur l'Éducation Bilingue et Plurilingue

\section{Printed version}

Date of publication: 1 December 2013

Number of pages: 101-105

ISSN: 1127-266X

\section{Electronic reference}

Michael Clyne, "Code switching ", Éducation et sociétés plurilingues [Online], 35 | 2013, Online since 01

February 2020, connection on 17 February 2021. URL: http://journals.openedition.org/esp/2827 ; DOI https://doi.org/10.4000/esp.2827 
ment le citoyen moyen peut-il s'en faire une idée et ne pas formuler face aux scientifiques des demandes élevées et souvent impatientes, en particulier dans le domaine des sciences humaines? Comment passer du langage des chercheurs et même dans un temps décalé à celui du grand public et des autorités? Et comment passer encore des résultats de la recherche aux applications politiques? In fine, l'on partage le regret de la limitation temporelle d'un PNR: dans le domaine des situations linguistiques, des études longitudinales s'imposent.

L'exposé que nous a fait lors du dernier Samedi matin du CIEBP à Paris le 16 mars 2013, Jean-François De Pietro («Quelques approches originales pour une didactique du plurilinguisme») illustre le programme ÉOLE, Éducation et ouverture aux langues de l'école: il peut être considéré comme une application importante dans la direction des recommandations du PNR 56. Nous en publierons le texte dans un prochain numéro de notre revue.

\section{Penelope GARDNER GHLOROS, Code switching. Cambridge: Cambridge University Press, 2009. Michael CLYNe (1)}

Readers of this journal are well aware of the explosion which the area of bi-/multilingualism/language contact has undergone in the past two decades. There are numerous new journals, conferences, handbooks and textbooks, and masses of monographs in the area. A central aspect of this study - one not clearly defined is code switching. So why do we need a new book entitled Codeswitching? It is a critical synthesis of the field, very accessible to specialists, linguists from other fields, and students being initiated into the field; a book that points the way to new approaches for decades to come - just what is needed at this time.

Penelope Gardner Chloros (hereafter GG) has contributed empirical sociolinguistic and descriptive linguistic studies to the literature on language contact for well over 20 years and is best known for her research on Alsatian-French bilingualism in Strasbourg and on Greek-English bilingualism in London. She is not one of the grand theorists of the field but has made available her innovative ideas, energy and experience to many collaborative ventures including the European Science Foundation Network on Code Switching (CS) and the LIDES bilingual data base project. GC's volume, perhaps more than any other, is characterized by an open-mindedness - not being wedded to any school or paradigm 
- and by an attempt to understand all the contributions the way their originators would wish them to be understood. One chapter each is devoted to CS and language contact, social factors in CS, conversational, grammatical and psycholinguistic approaches, and the acquisition of CS. There are introductory and concluding chapters.

Attitudes are a crucial topic that keeps cropping up throughout the volume. The book is about processes as well as products so that methodological approaches are also foregrounded. Transcription conventions are explained early (on page xii), typical of a book which is very user friendly.

Examples are derived from the author's and others' research data bases or from the media, signage, etc. not just in contact between European and Asian languages but in smaller and endangered languages. They also come from different historical periods, including antiquity - from Cicero (p 80) and from official and non-official sources in the Medieval period ( $\mathrm{p} 40)$.

The book is written in a captivating style - a pleasure to read and logically presented. Conclusions follow very directly from chapters, and there is clearly a development from chapter to chapter, which flow on. GG is constantly engaging with the reader as well as with the content and thereby encouraging the reader to develop their own relationship with the content.

The introductory chapter starts with examples explaining both what CS is and why it is worth studying, both for its own sake and for what it tells us about speech and language. The different types and functions of code-switching are outlined. In just a few words she is able to discuss terminology, main references, speakers' insights, and different types of CS.

The second chapter deals with the place of CS in language contact and its relation to borrowing, pidginization, convergence, 'mixed languages', and language shift - as she shows, codeswitching can indicate both convergence and differences.. Examples are very clearly explained, sometimes even beyond the coverage in the original source. Paradoxical and challenging issues such as whether CS signifies vitality or shift/death are discussed in a lively and lucid way.

The dichotomy social/structural factors is introduced in this chapter but becomes the focus of Chapter 3. This practice stresses the point that one needs to examine all aspects of CS to understand some of them. In Chapter 3, GC is able to utilize her own work on French-Alsatian bilingualism in Strasbourg and GreekEnglish bilingualism in London to explain different types of CS 
such as dense CS, triggering and (non-indexed) unmarked CS. Issues of identity and values are introduced, which will also inform the following chapter.

In Chapter 4 the emphasis is on conversational/pragmatic motivation of CS in which Myers-Scotton's rational choice approach is contrasted to the verbal action approach of Auer and Li Wei. But accommodation theory and the role of gender also enter the discussion on the role of CS in conversation (which includes humour, bonding, and dampening directness).

In Chapter 5, after a very brief overview of grammatical theories, GC discusses the role that grammar can play in the understanding of the importance and limitations of grammar in CS. GC's position as a sociolinguist is that grammatical approaches have not sufficiently addressed variation (p. 90). In this chapter, the examples are always of some tool, method or classification. Constraints proposed and their violations in different language contact pairs are dealt with as are (especially Myers-Scotton's MLF and Muysken's tripartite model). The relation between sociolinguistic and typological factors is considered in different types of code-switching and it is suggested that more studies of the same and different languages in different sociolinguistic environments could throw light on the primary determinants. GC agrees with Muysken that grammatical frameworks account less well for some types of CS than others.

Chapter 6 takes up psycholinguistic research of potential relevance to CS such as storage in the brain, separate and joint access to bilingual lexicon, encoding/production, and bilingual aphasia.

The discussion in Chapter 7 then proceeds to the acquisition of $\mathrm{CS}$, an innovative topic for a chapter in a book on language contact. GC's encyclopedic knowledge of the field enables her to capture the diversity of existing contributions to this topic, ranging from parental input studies and ones on pragmatic and linguistic development to Tabouret-Keller's description of CS acquisition in a family where CS is normal behaviour. GC then proceeds to classroom CS in bilingual education and the factors motivating this. An important point raised is the absence of studies on whether children brought up on CS are able to speak in a monolingual mode if required. Equally important is the need mentioned to take into account fully individual and contextual factors to understand CS in children.

The theme 'What is a language?' comes up in a number of ways throughout the book. GC criticizes the equation in much language contact research of 'language' with 'standard language' 
rather than the speaker's variety of the language. I regret that there is not much consideration of tri- and multilingualism, a field that has grown substantially in the past decade and a half. Particularly in the final chapter, formulations about CS seem to preclude three or more languages from consideration (eg 'the characteristics of the two contributing languages' p.172; 'Neither language is inhibited', p.174; The same applies to references: De Bot's adaptation of Levelt's speaking model for bilingualism (1992) is referred to but his adaptation for multilingualism (2004) is only mentioned in relation to bilinguals.

The climax of the book is the final conclusions. On $\mathrm{p} 164$ the question is raised: 'What do we know about CS?' GC's synthesis focuses on variation between individuals and between communities, internal variation, problems of analysis, need for interdisciplinary approaches.

GC pays attention to the fuzziness of CS and the studies that do justice to this. After 170 pages she summarizes 'the story so far' admirably:

1. There are problems defining CS so that the selection of a unit of analysis is crucial.

2. CS can be found in a wide range of situations, both macro (eg diglossia) and micro (accommodation and role in structuring conversation)

3. There is an identifiable relationship between the grammatical patterns of CS and the features of the constituent languages. GC rejects constraints or Base/matrix language with their 'external notion of what a language is' ( $p$ 173) rather than leaving the speakers to construct their own systems from the input.

4. While giving credit to some psycholinguistic studies such as Green's showing that CS occurs where neither (or no) language is inhibited, GG states that psycholinguistic research often relies on 'elite bilinguals' (standard speakers learning another standard language academically) often based on monolingual research. It generally ignores context.

5. There is only indirect research on children's or L2 learner's CS. She also proposes future directions of CS research:

1. Comparative studies to gauge the effect of different types of variables affecting CS.

2. Bring psycholinguistic research closer to the sociolinguistic requisite to consider natural language. She suggests basing the data on authentic recordings. (I wonder if such a radical departure from psycholinguistic methodology may be a lost cause Grosjean is unusual as a mediator between psycho- and sociolin- 


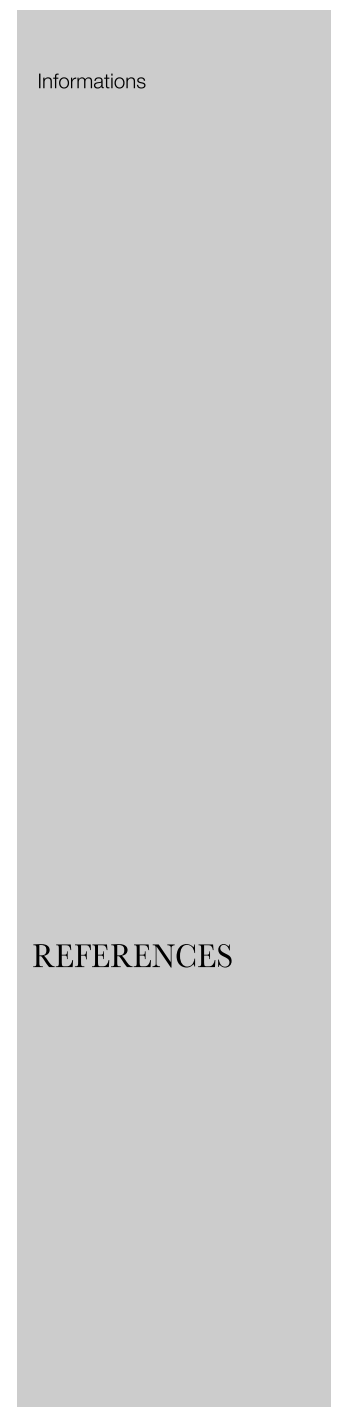

guistics.)

3. Increase in phonological studies of CS (underrepresented in the literature.)

GC ends with a plea for the acceptance of crossing and mixed lects, with which I concur.

I am not sure that I would welcome as enthusiastically as GC appears to do a dictionary. of 'Espanglish' by a professor of Espanglish at Amherst College, Mass. I would first like to know a lot more about norms and variation in American Spanish, which covers a wide range of national varieties and convergence between them, and who sets norms. The same applies to the translation of Don Quixote into 'Espanglish'. It reminds me of a controversy in the late 1970 s over the 'imitation' of American Swedish in the film The Emigrants. We need to be sure that the variety of a literary work is really a mixed variety and not an idiolect and that this is not interpreted by the speakers as a putdown. But this is a minor point of disagreement.

Code-Switching is a superb book which conveys an appreciation of the longterm presence of language contact phenomena, shows how ambivalence between languages is a natural state, and offers an approach for an increasingly plurilingual global future.

The appendix discusses methods of coding and analyzing plurilingual data which promotes comparability and collaboration.

DE BOT, K. 1992. A bilingual production model: Levelt's 'speaking' model adapted. Applied Linguistics 13, 1-24.

DE BOT, K. 2004. The multilingual lexicon: modeling selection and control. International fournal of Multilingualism 1, 17-32.

\section{FOOTNOTE}

(1) This review first appeared in International Fournal of Bilingualism, 14, 3: 369-372, 2010. 